Jurnal Administrasi Publik (Public Administration Journal), 10(2) December 2020

ISSN2088-527X (Print) ISSN2548-7787 (Online) DOI: https://doi.org/10.31289/jap.v10i2.3094

Jurnal Administrasi Publik (Public Administration Journal)

\title{
Analysis of Efforts to Increase Social Media Influencers Income Taxes in Endorsement Activities
}

\author{
Fernaldi Anggadha * \& Haula Rosdiana **
}

Tax Administration and Policy Study Program, Faculty of Administrative Sciences, University of Indonesia, Indonesia

Received: November 12, 2019; Reviewed: January 02, 2020; Accepted: July 23, 2020

*e-mail:aldi anggadhaha@outlook.com; **e-mail:haula.rosdiana2013@gmail.com

\section{Abstract}

Technological developments in the current era of globalization have brought changes to marketing techniques, namely by using social media. Marketing through social media is mostly done by influencers because it is easy to do and earns a fairly large income. The objective of this study is to analyze the efforts made by the Directorate General of Taxes to increase income tax on social media influencers in endorsement activities. This study adopted a post-positivism paradigm with qualitative methods. The objective of this research is descriptive. Primary data sources were obtained through in-depth interviews with selected informants. The results showed that the income of social media influencers or art workers has a large tax potential. The Directorate General of Taxes attempted to increase income tax revenue for influencers by updating databases, socializing and monitoring with law enforcement. The Directorate General of Taxes needs to provide confirmation of the taxation provisions on influencers' income so that it can provide equal tax treatment with conventional artist activities and close the tax loopholes that are widely used through online activities.

\section{Keywords: Income Tax, Influencer, Endorsement, Social Media}

How to Cite: Anggadha, F. \& Rosdiana, H. (2020). Analysis of Efforts to Increase Social Media Influencers Income Taxes in Endorsement Activities. Jurnal Administrasi Publik (Public Administration Journal). 10(2): 111-117 


\section{INTRODUCTION}

The era of economic globalization cannot be separated from the influence of the development of information technology, which has given birth to the internet. Now with the internet, the benefits are not only felt by the people in IT field, but all levels of society in the world, including business activists who really feel the benefits of the internet. Business actors in recent era will find the difficulty in developing, if they don't have a link that they can use to introduce their products, remembering many business rivals with similar products.

Data from a survey by the Indonesian Internet Service Providers Association (APJII, 2018), One reason for using the internet is for social media. By reason of the Indonesian people's hobbies are accessing social media, business people take advantage of this momentum to introduce their products through social media. Promotions with an endorsement model or a paid promotion by an influencer are quite popular in this globalization era along with the rapid growth of social media in Indonesia.

The increasing popularity of Instagram social media has been influenced by the effectiveness of influencers in product marketing (Vikansari \& Prasa, 2019). In other previous studies, it was stated that $80 \%$ of marketers found the influencers to be an effective marketing strategy (Damupolii, 2017). When it comes to online behavior, people seem to be more influenced by the internet today. Based on that statement, the presence of influencers has more influence on product awareness, purchase intention, and brand trust.

Endorse has been done by an influencer to the existence of endorsed goods will be very influential (Funchteiner \& Portz, 2017). People will be aware of a product / brand if the item is endorsed by influencers and people will be interested in buying goods / products if the item is endorsed by influencers, as confirmed by a survey conducted by Jakpat in 2019 (Jakpat, 2019) as in Figure 1.

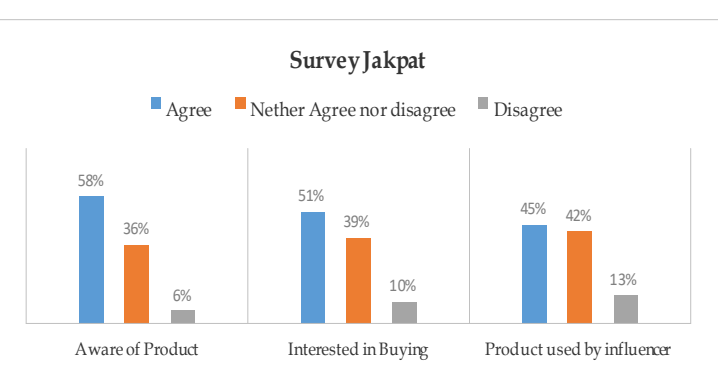

Figure 1 Central Jakarta Survey Source: JakPat Survey Report (2019)

Social media currently one of the most loved by Indonesian people, business people use this social media to gain benefits, one of which is by trading without having to go around introducing their products. It is enough to work together with influencers to market the products on social media. Influencers who promote goods will often receive endorsed services or a paid promotion of an item / product that is endorsed and get income from it.

In practice, the Social Media Influencer who is familiarly called Mael Lee in an interview on a television show stated that he can earn up to hundreds of millions of rupiah. For a single promo on Instagram he charges millions of rupiah, 7 million rupiah product photos, 11 million simple videos rupiah and a sketch of 17 million rupiah to broadcast 2 weeks in the feed (Anwar, 2019). In his interview at the Black and White event (26/02/2019), the man, whose real name is Haris Saputra, said that he can earn 500 to 600 million rupiah in a month through an endorsement on Instagram. Other celebrities such as Muhammad Rijal Mulyana, who is familiarly called Bang Ijal, for photo endorsement, the man who has 2.4 million followers charges 3 million rupiah for endorsements in the form of photos.

The potential for income from advertising activities posted via cyberspace is enormous. This advertising activity can be spread over a wide range, from domestic to global. In terms of taxation, this activity 
generates economic income or additional income, so that it is subject to tax. As of SE$62 / 2013$, income from services providing time and / or place in other media in order to convey information is an object of income tax that must be deducted from Article 23, Article 21 or Article 26 in accordance with applicable regulations (Oktapyani \& Purwani, 2018 ).

Table 1 Compliance Map of 154 Taxpayers of Endorsement

\begin{tabular}{|c|c|c|c|c|c|}
\hline \multirow[b]{2}{*}{$\begin{array}{l}\text { Status } \\
\text { Report }\end{array}$} & \multirow[b]{2}{*}{$\begin{array}{l}\text { SPT } \\
\text { status }\end{array}$} & \multicolumn{2}{|l|}{2016} & \multicolumn{2}{|l|}{2017} \\
\hline & & $\begin{array}{l}\text { Number } \\
\text { of } \\
\text { reports }\end{array}$ & $\begin{array}{l}\begin{array}{l}\text { Amount } \\
\text { (more) } \\
\text { taxes }\end{array} \text { to pay } \\
\end{array}$ & $\begin{array}{l}\text { Number } \\
\text { of } \\
\text { reports }\end{array}$ & $\begin{array}{ll}\text { Amount } & \text { less } \\
\text { (more) to pay } \\
\text { taxes }\end{array}$ \\
\hline Report & KB & 51 & IDR $1,859,503,433$ & 53 & IDR $2,402,583,154$ \\
\hline & LB & & - & 1 & IDR $2,479,615$ \\
\hline & Nil & 36 & - & 34 & - \\
\hline No Report & & 67 & - & 66 & - \\
\hline Total & & 154 & $\begin{array}{l}\text { IDR } \\
1,859,503,433\end{array}$ & 154 & $\begin{array}{l}\text { IDR } \\
2,040,103,539\end{array}$ \\
\hline
\end{tabular}

Table Source: Analysis results (2019)

Taxes on influencers and endorsement activities can certainly increase Indonesia's tax revenue. Seeing the large amount of money that occurs in social media activities. The Directorate General of Taxes estimates that the potential tax revenue that can enter the state asset from this business reaches US \$ 1.2 billion or the equivalent of 15 trillion rupiah (Hasibuan, 2019). But so far, the compliance of social media influencer taxpayers is still lacking. From the data obtained from 2016 and 2017, there are still many taxpayers who have not reported their tax obligations, this is supported by data that can be seen in table 1 . Of course the potential revenue for endorsement activities carried out by these massive influencers has been still not optimized yet, therefore the Directorate General of Tax (DGT) as the tax authority in Indonesia is required to optimize or increase the income tax of social media influencers on endorsement activities.

Taxation policy is a policy related to determining what is the tax base, who is exempted, what is used as a tax object, what is excluded, how to determine the amount of tax owed and how to determine procedures for implementing payable obligations (Mansury, 1999). Tax policy is a representation of the grand design or blue print of human development, the economy of a government, and legislators (Rosdiana \& Irianto, 2011).

Income Tax is a tax imposed on tax object and / or entities, on income received or earned during a tax year. Income tax is an official levy addressed to people who earn or receive income received or earned during the tax period or year for the benefit of the state and society in living as nation and state as an obligation (Official, 2003).

The subjects of income tax are individuals and entities or parties to which the laws and regulations are referred to be taxed (Waluyo, 2011). Tax subjects who have fulfilled subjective tax obligations will later become taxpayers, namely tax subjects who really have to pay income tax. The tax subject is divided into 2, namely domestic tax subjects and foreign tax subjects.

The objects of income tax are all additional economic capabilities received or obtained by taxpayers, either from domestic or foreign origin, which are used to increase the wealth of the taxpayer or for consumption, in any names and forms. If it is seen from the additional economic capability, the income grouped into (a) Income obtained from work in the context of work relations and independent employment such as salaries, honoraria, and so on; (b) Income from business activities (business income); (c) Passive 
income, namely capital or investment, in the form of movable or immovable assets such as interest, dividends, royalties, rent, profits from the sale of assets or rights that are not used for business and so on; and (d) Other income, such as debt relief, gifts, etc. (Rosdiana \& Prasetyo, 2003).

\section{RESEARCH METHODS}

This study used a qualitative approach. It is based on the notion of a qualitative approach (Creswell, 1994):

"A qualitative study is designed to be consistent with the assumptions of qualitative paradigm. This study is defined as an inquiry process of understanding a social or human problem, based on building a complex, holistic picture, formed with word, reporting detailed view of informations, and conducted in a natural setting "

Based on the above understanding, the qualitative approach is a research process that focuses on phenomena carried out in natural settings and the qualitative approach tries to understand the phenomenon more deeply with all its complexity. A qualitative approach was used by researchers to understand the phenomena related to the analysis of the Directorate General of Taxes efforts to increase income tax on social media influencers in endorsement activities. The data collected were obtained from several supporting sources and the study was carried out in a natural setting and the researcher as the main instrument in analyzing the data. Based on the objectives of the study, the type of study used in this study is descriptive, because this study is to describe what the Directorate General of Taxes efforts to increase income tax on endorsement activities were done by social media influencers.

In this study, two techniques were used to collect information and data, namely: (a) The field study in this study used an intense and in-depth interview technique. In-depth interviews were conducted with DGT, taxpayers, and practitioners, and (b) The literature study in this study used literature collection and study techniques such as journals, theses, previous books, articles, government regulations, and laws. The research site used was a location that has taxation authority, which in this case is the Directorate of Taxation Regulations II, the Directorate of Potential Compliance and Acceptance, the Directorate of Tax Information Technology, the Directorate General of Taxes on Jalan Gatot Subroto No. 40-42 Jakarta 12190.

\section{RESULTS AND DISCUSSION Efforts to Update Influencer Taxpayer Database}

The organization in this case the DGT with taxation issues must have a fundamental initiative in drafting legislation that can adapt to changes in the internet sector, namely as a solution to social media taxation problems (Kaplanhan \& Korkut, 2016)

In making efforts to increase tax revenue from the Influencer sector, improvements are needed in matters relating to tax compliance, one of the main things is from the DGT database, according to Andri, an analyst at the Directorate of Potential Compliance and Acceptance (PCA). :

"In my opinion, starting from the database first, DGT must improve the existing data. The main concern in DGT is the data problem. For the influencer problem, it would be great if we, the DGT, have a database of WPWPs, especially influencers who like to endorse data, who are influencers in Indonesia, how many lists, we collect their data, we try to appeal, both the WP and the employer. "(Monday, October 14, 2019).

According to the DGT, the database is the first thing to be fixed before taking the next step in an effort to increase tax revenue. If you obtain accurate data, the DGT has the power to catch taxpayers who 
have not complied. Clarification cannot be done without accurate data, therefore data is very much needed to clarify the taxpayers, so that taxpayers cannot evade when it is questioned by the DGT. This is in accordance with Andri's statement, an analyst at the Directorate of Potential Compliance and Acceptance (PCA):

"If there are data, we can clarify it. If there is no clear clarification, we can immediately carry out an investigation. For example, from the head office, we collect the names of influencers in Indonesia, for example, we get 4000 . Later, from 4,000 we are clustered into whichever regional office, later we will try to ask representatives of the regional office to conduct socialization to convey to KPP to carry out an appeal process to influencers or to employer." (Monday, October 14, 2019).

DGT attempted to update the data by clarifying related parties such as the employer, DGT will get data on how much income the influencer earns. These data will later be used as a benchmark for taking the next steps. The mapping of players is very important to do, so that they are right on target in carrying out appeals and other monitoring steps. To synergize both influencer service users and any influencers who have been detected in order to produce a strong database. Until nowadays, DGT does not deny that DGT's weakness in taking action against taxpayers is data problems, so the first step taken by DGT in seeking this is by first correcting data. The DGT admitted that in the efforts to update the data, there were many obstacles that were quite difficult because the data they had were not accurate enough, not only registered artists, but now ordinary people can become influencers. As stated by Andri, Analyst at the Directorate of Potential Compliance and Acceptance (PCA):

"The difficulty is that our data does not have a real benchmark, the data from Google is not valid about the income that influencers get. We also have trouble calculating how many potential endorsements are there. Not only that, we have contacted the wrong social media, most social media offices protect the data of their users so we have a little difficulty obtaining and developing the data we have. However I heard that we will have a system named social network analytics which will help add to our data because later it will be integrated with social media. " (Monday, October 14, 2019).

The main challenge for DGT was to obtain comparative data. Comparative data was needed to test the correct submitted taxpayer reports in accordance with the provisions. However, DGT is still optimistic about carrying out this process, because it has become a special concern of the government in general by making a roadmap for handling digital transactions. The assessment stage is still being carried out by mapping players or actors in endorsement and influencer activities.

\section{Outreach Efforts to Influencer Taxpayers}

To deal with endorsement activities carried out by social media influencers, DGT has made several efforts, one of them is by socializing based on Andri's statement, an analyst at the Directorate of Potential Compliance and Acceptance (PCA):

"So far we have carried out socialization, we have also clustered the WP-WPs we have seen from the most followers. The general socialization here has invited artists, YouTubers, and other influencers, at the head office level, we have socialized and we have also done it. We have been actively reporting in the media about the problem we have started to catch up with influencer WPs, while at the KPP level as far as I know, we have also conducted 
socialization. At least they realize that the DGT actually knows that they have income from the endorsing activities they are doing now. " (Monday, October 14, 2019).

DGT has conducted socialization especially for artists, YouTubers, and influencers. It was done to educate taxpayers who still do not understand their obligations as tax subjects. One result of these outreach efforts. In addition, the DGT has also been aggressively socializing through the mass media by reporting that the tax obligations for endorsement activities are the same as there is no new tax base and DGT has paid attention to and will detect taxpayers who have income from their profession as an influencer. Based on the information from the DGT, providing socialization both directly and through news in the mass media should be enough to make influencers realize that their income from endorsement activities can be taxed.

\section{Supervision Efforts through Law Enforcement}

DGT challenges also exist in terms of supervision. It cannot be denied that the level of difficulty in monitoring activities carried out through online media is higher than a physical one. To optimize tax revenue, DGT conducts law enforcement on taxpayers whose compliance is still low, according to Andri's statement, an analyst at the Directorate of Potential Compliance and Acceptance (PCA):

"First, we will appeal, clarify to the taxpayers concerned, and strengthen data as our material to enforce the law, if notice and clarification have been done but do not have accurate data about the data, so back to the first problem, namely data that must be strengthened. It also enters into extensification and intensification of taxes. " (Monday, October 14, 2019).

This persuasive notice process was carried out to clarify taxpayers. First of all by capturing taxpayer who were allegedly an influencer who carried out endorsement activities. Then check the compliance of the taxpayer through the previously reported SPT, then lowered to the Regional Office and KPP level, so that clarification can be made before taking audit action. If something was found that is not in accordance with the tax provisions, it will be examined. This is in accordance with Andri's statement, an analyst at the Directorate of Potential Compliance and Acceptance (CRA):

"We check the compliance, check the SPT, have we entered the income from the endorsement or not. After that we strongly urge the taxpayers. After the analysis is carried out, we try to urge the taxpayers to try to clarify their income in connection with the endorsement that has not been submitted to the SPT, like that. " (Monday, October 14, 2019).

This effort is also included in tax extensification and intensification efforts, so that in the future taxpayers are expected to be more obedient and can significantly increase tax revenue from the sector. To respond it, the DGT also carried out monitoring measures for endorsement activities involving influencers, namely according to Andri's statement, an analyst at the Directorate of Potential Compliance and Acceptance (PCA):

" we just doing law enforcement, in the form of making a persuasive notice through the KPP, for example we can later appeal to the WP-WPs in Jakarta from the head office or from the regional office and then clustering the WP-WPs in Jakarta which were considered as influencers, we continue to list them, we check their compliance. For example, if they haven't obeyed or have complied, but it's not right for us to make a notice to report the income from his endorsement as an influencer, if for example the taxpayer is still stubborn, then we'll carry out such an 
examination. " (Monday, October 14, 2019).

DGT takes supervision steps through law enforcement, namely law enforcement in the form of providing persuasive notice before taking audit action in response to potential loss arising from endorsement activities carried out by influencers.

\section{CONCLUSION}

The Directorate General of Taxes (DGT) has made efforts to increase income tax revenue for influencers in endorsement activities, namely by collecting data so that it can become a real database and can be used as a benchmark for the following years and DGT has created an analytic network system (SONETA) with expectation that more data will be collected because SONETA will later be able to connect to social media, carry out intensive socialization, either face-to-face or socialization through mass media, supervise with law enforcement, namely giving persuasive notice to influencer taxpayers before follow up into the realm of investigation.

\section{BIBLIOGRAPHY}

AICPA. 2017. Guiding Principles of Good Tax Policy: A Framework for Evaluating Tax Proposals. Washington: AICPA. Diambil kembali dari AICPA: https://www.aicpa.org/ Tanggal 13 Oktober 2019

Anwar, Syaiful. 2019. Terungkap, Segini Tarif Endorse Maell Lee 'Bukan Kaleng-kaleng' di Instagram. Diakses Tanggal Oktober 10, 2019.

dari

https://kaltim.tribunnews.com/2019/03/05 tterungkap-segini-tarif-endorse-maell-leebukan-kaleng-kaleng-di-instagram/.

APJII. 2018. Asosiasi Penyedia Jasa Internet Indonesia. Diakses September 22, 2019 dari www.APJII.com
Creswell, John W. 1994. Research Design: Qualitative and Quantitative Approaches. California: SAGE Publication, Inc.

Damupoli, I. N. 2017. Pajak Penghasilan pada Kegiatan Youtuber dan Selebgram dalam Penggunaan Media Sosial Berdasarkan Undang-Undang Nomor 36 Tahun 2008 tentang Pajak Penghasilan. Lex Privatum. $5(3)$

Funchteiner, P., \& Portz, K. 2017. A Case Study Of Accounting And Tax Treatment Of Celebrity Endorsment Contracts. Journal Of Business Cases And Apliction, 20(2).

Hasibuan, Muhammad Iqbal. 2019. Selebgram, Aktivitas Endorsement dan Pajak. diakses tanggal Oktober 14, 2019. dari https://metrojambi.com/read/2019/04/03 /43337/selebgram-aktivitas-endorsementdan-pajak/

JakPat. 2019. The Power of Social Media Influencer. diakses tanggal Oktober 14, 2019 Diunduh dari https://blog.jakpat.net/the-power-ofsocial-media-influencer/

Kaplanhan, F., \& Korkut, C. 2016. Untaxed SocialMedia Problem and Potential Solutions. 135-152Anwar, S. (2019, 03 05). Tribunnews. Retrieved from Kaltim Tribunnews.

Mansury. 1999. Kebijakan Fiskal. Tanggerang: YP4.

Oktapyani, N. A., \& Purwani, S. P. 2018. Tinjauan Yuridis Pengenaan Pajak Penghasilan Terhadap Kegiatan Endorsment Dalam Media Sosial. E-Journal Universitas Udayana.

Resmi, S. 2003. Perpajakan. Jakarta: Salemba Empat.

Rosdiana, H., \& Irianto, E. S. 2011. Panduan Lengkap Tata Cara Perpajakan di Indonesia. Jakarta: Visimedia.

Rosdiana, H., \& Prasetyo, A. 2003. Pengantar Perpajakan: Konsep, Teori dan Aplikasi. Jakarta: Yayasan Pendidikan dan Pengkajian Perpajakan.

Vikansari, N. S., \& Prasa, I. W. 2019. Pengawasan Pengenaan Pajak Penghasilan Terhadap Youtubers Sebagai Pelaku Influencer di Platform Media Sosial Youtube.E-Journal Universitas Udayana.

Waluyo. 2011. Perpajakan Indonesia. Jakarta : Salemba Empat. 